\title{
The Predicament and Countermeasures during Sustainable Development of Our Resource-oriented Cities
}

\author{
Fanhua MENG, Meitian ZHAO \\ School of Business, North China Institute of Science and Technology, Sanhe, Hebei, China
}

\begin{abstract}
With the development of the economy, issues involving of environment and eco-environment security are getting more and more conspicuous. How to realize sustainable development for resourceoriented cities that rely largely on resources arose people's concern. For resource-oriented cities, to realize sustainable development is very likely to fall into the dilemma of environmental pollution, low efficiency of the usage of resources and high cost of transformation. On the basis of different characteristics of resourceoriented cities in different stages, we can take corresponding measures to enhance their ability of achieving sustainable development and ultimately reach the goal.
\end{abstract}

KEYWORDS: Resource-oriented cities; Sustainable Development; Predicament; Countermeasures

\section{THE OVERVIEW OF SUSTAINABLE DEVELOPMENT}

Since 1980s, the problem of environment and ecological security is becoming more and more serious, the concept of sustainable development has been widely recognized and accepted by many countries. Two programmatic documents have been passed by the United Nations Conference on Environment and Development in 1992, which are "Rio de Janeiro declaration" and "twenty-first Century agenda". After this event, the concept of sustainable development has been widely accepted by all the countries.

\subsection{The meaning of sustainable development}

The judgmental standard of sustainable development is its capacity. The description of "Twenty-first Century agenda" on the capacity of sustainable development is that, the ability of sustainable development of a country depends largely on the ability of its people and system under ecological and geographical conditions. Specifically speaking, the capacity of construction includes the fostering and enhancement of the country on their human resources, science, technology, organization, institutions and resources. The essence of sustainable development is the harmony between human and nature, and the harmony between humans. It covers contents in three closely related aspects, ecological sustainability, economical sustainability and sociological sustainability. Among which, ecological sustainability is the fundamental factor, the second is the prerequisite and the third is the purpose.

\subsection{The principle of sustainable development}

The principle of sustainable development includes principle of sustainable development, the common principle and fairness principle. The principles of sustainable development refers to the development of human economy and society must be maintained within the scope of the resources and environmental carrying capacity, in order to further ensure sustainable development. We should not only restrain our own behaviors on the usage of resources and put emphasize on the protection of the environment, but also preserve and reinforce the construction of the resource base in the purpose of restoring the quality of the environment. The common principle refers to the ecological system that human share and rely is an open entirety. Modern global environment, economy and the sociological system are becoming increasingly interdependent and further more developed into a composite system that is indivisible. Only when we have done a good job of coordinating the sociological system and the natural ecosystem, making proper coordination between human social subsystems, can we achieve the final goal of sustainable development. The fairness principle should at first be fair to nature, admit and accept their values, respect, cherish and protect the natural environment. The purpose of sustainable development is to meet everybody's needs, not only include intergenerational equity that everyone has the chance to acquire the limited resources and the achievement of development, but also requires the equality between generations. 


\section{THE PRESENT SITUATION OF THE RESOURCE- ORIENTED CITIES OF OUR COUNTRY}

\subsection{The meaning of resource-oriented city}

There is still no agreed criteria of the meaning of resource-oriented city, different scholars have given different explanations from different perspectives. Among which, the main idea covers angels of the structure of economy, the major function of resource-oriented cities. In "The opinions of the State Council on the promotion of resource-oriented cities", the orientations of resource-oriented cities are as below. Resource-oriented cities which include resource-oriented areas are cities or areas that put exploiting and processing their mineral and forest resources as their leading industry.

\subsection{Current situation of resource-oriented cities}

According to the orientation of resource-oriented cities in "State Council's several opinions on promoting sustainable development of resourceoriented cities", and statistics of the research group of "the transformation on the economic structure of resource-oriented cities from the National Development and Reform Commission. There are 118 resource-oriented cities, which account for $18 \%$ of the number of cities, with a total population of 154000000 people. Currently, 2 / 3 has entered the "old age", 440 mines will be closed among the stateowned mines that were exploited in the 1950s. Among the 390 mine cities, 50 of them were resource-exhausted, lives of 3000000 laid-off workers, 10000000 family members of employees are affected. For detailed information, please refer to Table 1.

Resource-oriented cities are mainly industrialized in coal, oil, iron ore and copper. Among the 118 resource-oriented cities, there are 63 coal cities, which accounted for 53\%, 21 forest cities accounting for $18 \%, 12$ non-ferrous metallurgical cities, 9 oil cities, 8 black metallurgy cities, meanwhile, there are 5 other cities accounting for $10 \%, 8 \%, 7 \%$ and $4 \%$.

According to the "State Council's several opinions on promoting sustainable development of resource-oriented cities", the national first batch of resource exhausted cities are determined by The National Development and Reform Committee, 12 cities are included, among which, 3 of them are typical resource-exhausted cities, locating in the central part of China, which are Jiaozuo, Pingxiang and Daye (county-level city). Meanwhile, 5 of them are the resources urban economy reforming experiment site cities, which are Fuxin, Yichun, Liaoyuan, Baishan and Panjin. There are also 3 typical resource-exhausted cities which lies in ShiZuishan, Baiyin and Gejiu (The county-level city). Daxinganling district is the only typical resource-exhausted district among all these.

Table1: Current situation of resource-oriented cities in the country.

\begin{tabular}{|c|c|c|}
\hline & $\begin{array}{l}118 \text { resource- } \\
\text { oriented cities }\end{array}$ & $\begin{array}{l}60 \text { typical } \\
\text { resource- } \\
\text { oriented cities }\end{array}$ \\
\hline The total area of land & \begin{tabular}{|l|}
960000 \\
square \\
kilometers
\end{tabular} & $\begin{array}{l}460000 \text { square } \\
\text { kilometers }\end{array}$ \\
\hline $\begin{array}{l}\text { The total population } \\
\text { involved }\end{array}$ & $\begin{array}{l}154000000 \\
\text { people }\end{array}$ & $\begin{array}{l}66500000 \\
\text { people }\end{array}$ \\
\hline $\begin{array}{l}\text { The number of workers } \\
\text { involved }\end{array}$ & $\begin{array}{l}12500000 \\
\text { people }\end{array}$ & $\begin{array}{l}8000000 \\
\text { people }\end{array}$ \\
\hline $\begin{array}{l}\text { The number of registered } \\
\text { unemployed workers }\end{array}$ & $\begin{array}{l}900000 \\
\text { people }\end{array}$ & 560000 people \\
\hline $\begin{array}{l}\text { The proportion of } \\
\text { unemployed workers }\end{array}$ & $7.20 \%$ & $7.00 \%$ \\
\hline $\begin{array}{l}\text { Comparison on the average } \\
\text { percentage of the } \\
\text { proportion of unemployed } \\
\text { workers of the city workers }\end{array}$ & $\begin{array}{l}\text { 2.3percentage } \\
\text { higher }\end{array}$ & $\begin{array}{l}2.1 \text { percentage } \\
\text { higher }\end{array}$ \\
\hline GDP in 2000 & $\begin{array}{l}1.155 \text { trillion } \\
\text { Yuan }\end{array}$ & $\begin{array}{l}586 \text { billion } \\
\text { Yuan }\end{array}$ \\
\hline Per capita GDP in 2000 & 7500Yuan & 8810 Yuan \\
\hline $\begin{array}{l}\text { Comparison on the Per } \\
\text { capita GDP and the } \\
\text { average level of whole city }\end{array}$ & $\begin{array}{l}\text { 1150Yuan } \\
\text { lower }\end{array}$ & $\begin{array}{l}\text { 160Yuan } \\
\text { higher }\end{array}$ \\
\hline $\begin{array}{l}\text { Annual average wages of } \\
\text { staff and workers }(2000)\end{array}$ & 7800Yuan & 8180Yuan \\
\hline $\begin{array}{l}\text { Comparison on the annual } \\
\text { average wages of staff and } \\
\text { workers and the city's }\end{array}$ & $\begin{array}{l}\text { 1700Yuan } \\
\text { lower }\end{array}$ & $\begin{array}{l}\text { 1300Yuan } \\
\text { lower }\end{array}$ \\
\hline
\end{tabular}

* Data sources: "economic research" in 2002 eleventh

As is known to all ,the development of resourceoriented cities mainly rely on the industrial chain that was extended from the process of exploitation and utilization, thus a situation of single industrialized structure and limited developing space was formed .In order to achieve the purpose of sustainable development, many obstacles should be swept during the process.

\section{3THE DIFFICULTY OF REACHING THE GOAL OF SUSTAINABLE DEVELOPMENT OF RESOURCE-ORIENTED CITIES}

\subsection{Environmental Pollution}

The first biggest problem is environmental pollution, including the devastation of water, gas and soil.

According to the report of environmental statistics, the industries whose emission load of industrial solid waste are over 1 million tons are coal mining and washing industry, non-ferrous metal mining industry, black metal smelting industry and black metal mining industry in 2006. The percentage can reach $69.9 \%$ of the total amount. Take the exploitation of coal mines for example. The damage to the environment by this process can be illustrated in Table 2. 
Table 2: The damage to the environment by the exploitation and utilization of coal mines of China.

The national storage of coal gangue in 2005 was over 4000 million tons, with the annual production capacity accounting for about $10 \%$ of coal production.

The area of ground collapse which is caused by the exploitation of coal mines was over 700000 hectares.

The emission load of methane in 2005 reached about 14 billion cubic meters.

The emission load of carbon dioxide in 2005 was 25.49 million tons , among which $85 \%$ of them are emitted by the burning of coal mines.

According to the calculation of Japanese Institute of energy economics, the emission load of carbon dioxide of China in 2003 was 1127 million tons, which took a percentage of 16.4 in the total emissions of the whole world, and 918 million tons are emitted by burning coal mines, with a percentage of $32.9 \%$.

* Data sources: 2006 energy data

\subsection{Low efficiency of resource utilization}

China is a resource producing country, but also the largest consumer of resources. With the extensive exploitation of resources, the scarcity of resources and waste of resources are coexisted. As is shown in table 3 and 4 , in terms of the production of world primary energy, the production of oil lies in the third place, with gas in the third place and coal mines in the first. The amount of primary energy consuming is only behind America, in other words, in the second place. Thus, our resources are scarce.

Table 3: The top 3 of Primary energy production in the world (2005)

\begin{tabular}{|c|c|c|c|}
\hline & America & China & Russia \\
\hline Oil & 310.2 & 180.8 & 470.0 \\
\hline Gas & 473.1 & 45.0 & 538.2 \\
\hline Coal & 576.2 & 1107.7 & 137.0 \\
\hline Nuclear electricity & 185.0 & 11.8 & 33.9 \\
\hline Water electricity & 60.6 & 90.8 & 39.6 \\
\hline Total & 1606.0 & 1436.1 & 1218.7 \\
\hline
\end{tabular}

In the meantime, due to the level of production technology and ideology, the efficiency of exploitation of China's resources is very low, and many resources are seriously wasted.

"The plan on science and technology to promote the formulation and construction of resource protection and resource-saving society ", which is implemented by the Ministry of science and technology and social development indicated that the recovery rate of our metal mine mining is 10 to 20 percentage point slower than international level. The average rate of comprehensive utilization of mine resources is only $20 \%$, about $2 / 3$ of the symbiosis, associated useful component of mine are not exploited, which makes the usage rate of tailings is only $10 \%$.Every year in the process of developing mineral resources ,the loss value is about 78 billion Yuan.
Table 4: World primary energy consumption and structure (2005)

\begin{tabular}{|c|c|c|c|c|c|c|}
\hline & $\begin{array}{c}\text { Primary } \\
\text { energy } \\
\text { consumption }\end{array}$ & Oil & Gas & Coal & $\begin{array}{c}\text { Nuclear } \\
\text { electricity }\end{array}$ & $\begin{array}{c}\text { Water } \\
\text { electricity }\end{array}$ \\
\hline America & 3338.0 & 40.4 & 24.4 & 24.6 & 8.0 & 2.6 \\
\hline China & 2220.0 & 21.1 & 2.7 & 69.6 & 0.8 & 5.8 \\
\hline Russia & 970.9 & 19.1 & 53.6 & 16.4 & 5.0 & 5.8 \\
\hline Japan & 749.4 & 46.5 & 13.9 & 23.1 & 12.6 & 3.8 \\
\hline India & 553.3 & 29.9 & 8.5 & 55.0 & 1.0 & 5.6 \\
\hline Germany & 462.9 & 37.5 & 23.9 & 25.3 & 11.4 & 1.9 \\
\hline Canada & 453.6 & 31.5 & 25.9 & 10.2 & 6.6 & 25.7 \\
\hline France & 374.4 & 35.5 & 15.4 & 5.1 & 39.1 & 4.9 \\
\hline The UK & 324.7 & 36.5 & 37.4 & 17.2 & 8.1 & 0.7 \\
\hline Korea & 320.9 & 47.0 & 13.3 & 24.4 & 14.8 & 0.5 \\
\hline Brazil & 277.9 & 43.0 & 9.4 & 6.9 & 1.1 & 1.9 \\
\hline Italy & 262.7 & 43.0 & 9.4 & 6.9 & 1.1 & 39.6 \\
\hline Iran & 231.4 & 48.4 & 49.1 & 0.7 & - & 5.2 \\
\hline $\begin{array}{c}\text { Saudi } \\
\text { Arabia }\end{array}$ & 214.0 & 58.2 & 41.8 & - & - & - \\
\hline Spain & 210.6 & 53.5 & 19.7 & 14.5 & 8.8 & 3.5 \\
\hline Mexico & 210.3 & 59.6 & 30.0 & 4.1 & 1.6 & 4.3 \\
\hline $\begin{array}{c}\text { EU(25 } \\
\text { countries) }\end{array}$ & 2450.1 & 40.8 & 24.7 & 17.4 & 12.9 & 4.1 \\
\hline $\begin{array}{c}\text { OECD } \\
\text { The whole } \\
\text { world }\end{array}$ & 15053.0 & 36.4 & 23.5 & 27.8 & 6.0 & 6.3 \\
\hline
\end{tabular}

\subsection{The cost of transformation is high}

The appropriate timing should be chosen seriously in order to reach the goal of sustainable development of resource-oriented cities. However, these cities were mostly formed in the time of the planned economy. Thus, the cost for their transformation is bound to be high. It includes the exit costs of traditional industry, the cost of environmental governance and the establishment of a social security system for ecological restoration, the cost of separating resource-based enterprises running social functions, the cost of transformation of industrial entry barriers, social security cost, cost of raising money, cost of the friction, delaying and modifying of transformation and so on. These costs are a major problem during the process of reaching the final goal. Layout of text

\section{THE SOLUTIONS AND MEASURES TO THE PROBLEM SOLVING IN THE PROCESS OF ACHIEVING SUSTAINABLE DEVELOPMENT}

Various difficulties as there are, we still can take relevant measures to deal with them according to the different features during the process, thus enhance the ability of sustainable development and reach the final purpose of it.

In the perspective of the formation and processing of resource-oriented cities, natural resources are the core element of sustainable development in the early stage, the improvement of resource-oriented cities are essential in the mid period, and the last period 
mainly relies on the support of regional generalized resources. Based on the ability of the evolution of sustainable development, we can divide it into four stages, which are the initial stage, growing stage, maturity and recession. During this process, the promoting source of its sustainable development are the guarantee of resources, the supporting system of resource-oriented industry and the regional resources. The advantages and disadvantages of these cities are different, therefore, we should deal with them differently accordingly.

\subsection{Countermeasures and measures of the initial period}

For resource-based cities, their main advantages lie in the mining industry started in the initial stage, the agglomeration of mine workers and the establishment of mining districts. On the other hand, the disadvantages are the imbalance of input and output, the low efficiency of workers. Featuring on these, we are supposed to focus more on the reduction of costs in the process of the exploitation of subject products. We'd better adopt the cost leading strategy, actively develop the city's sustainable development and lay a solid foundation for the sustainability of the cities' renewal.

In this stage, mining towns should occupy less land, reduce the damage to the trees, grass and water as far as possible. Focus on the protection of resource development.

\subsection{Countermeasures and measures during the growing period}

In the growing period, because of the fast development of the mining industry, the processing of the urbanization and the enlarging of the city's population, pollution is getting severe and the ecoenvironment is deteriorating. Thus, we should properly handle the waste, waste water, waste gas caused by large-scale mining, in the purpose of reducing the extent of pollution to the environment. In the meantime, differentiation strategy of the main industry should be implemented for the sake of the effectiveness of the expanding ability during the process of achieving sustainable development. Strengthen the comprehensive exploitation of resources and reduce waste of resources. In China's nonferrous metal industry, there are 45 associated minerals, by mineral smelting and processing, 33 of them can be recycled. Ferrous metal industry involves more than 30 kinds of associated components, over 20 of them can be recycled, 20 kinds of common associated minerals of coal industry can be recycled.

\subsection{Countermeasures and measures of the mature period}

In the maturity stage, the exploitation of resources is in the peak period, the accumulation of funds is to speed up, the worsening exploiting conditions pose a threat to the benefit of economy. In this critical juncture, previous preparation should be done by resource-oriented cities, the capacity of achieving sustainable development should be focused, the level of management and technology should be uploaded to extend the mining period. Pay attention to the transformation from preliminary working to further processing and comprehensive processing. The standard of technology should be promoted in order to boost the transformation of way of developing economy from extensive form to intensive pattern. Reclamation should be regarded as one of the necessary measures of the economic activities in the growing period, which consists of tearing down useless constructions, dealing with exhausts, water purifying, restoration of farmland and forest planting, etc.

\subsection{Countermeasures and measures during the recession period}

In the recession period, the main focus lies on the updating of its capacity of sustainable development, during which period, the infrastructure in the cities are almost completed, the level of science and technology service is mostly started in a bright way, the industry of starting new undertakings begins to develop. Whereas, a serious situation began to appear, stagnation of the main industry, the declining of city economy, large numbers of workers are laid off and financial difficulties. Thus, the innovation of industry is surely to be the countermeasure for resource-oriented cities to achieve the goal. Boosting the transformation of the industrial structure, further enhancing the overall economic strength of the city and improving the city's comprehensive competitiveness are the essential points. In order to fulfill this goal, we should make a thorough plan of the development of the whole city, especially make good use of the hinterland of resource-based cities, making it the economic center of the whole city. Repositioning of the city function and taking advantage of the financial support from the society are both excellent ways to helping achieve its transformation successfully, in the end reaching the ultimate goal of sustainable development.

\section{REFERENCES}

[1] Yunjun Zhao. Chinese overview on economic sustainable development research. Economy, 2004 (5).

[2] Hailin Zhou. Research on evaluation index system of sustainable development of resource-oriented cities. Regional study and development. 2000 (3).

[3] Guancen $\mathrm{Wu}$, Youzhao Liu, Guanghui $\mathrm{Fu}$. The transformation of resource-oriented cities' assessment system under the idea of sustainable development Resource development and market. 2007(23). 